\title{
The origins of limnetic forms and cryptic divergence in Gnathopogon fishes (Cyprinidae) in Japan
}

\section{$\operatorname{AUTHOR}(S)$ :}

Kakioka, Ryo; Kokita, Tomoyuki; Tabata, Ryoichi; Mori, Seiichi; Watanabe, Katsutoshi

\section{CITATION:}

Kakioka, Ryo ...[et al]. The origins of limnetic forms and cryptic divergence in

Gnathopogon fishes (Cyprinidae) in Japan. Environmental Biology of Fishes 2013, 96(5): 631-644

\section{ISSUE DATE:}

2013-05

URL:

http://hdl.handle.net/2433/178668

\section{RIGHT:}

The final publication is available at link.springer.com; This is not the published version. Please cite only the published version.; この論文は 出版社版でありません。引用の際には出版社版をご確認ご利用くださ い。 


\section{The origins of limnetic forms and cryptic divergence in Gnathopogon fishes}

2 (Cyprinidae) in Japan

3 Ryo Kakioka $\cdot$ Tomoyuki Kokita $\cdot$ Ryoichi Tabata $\cdot$ Seiichi Mori $\cdot$ Katsutoshi Watanabe

6 R. Kakioka $\cdot$ R. Tabata $\cdot$ K. Watanabe

7 Graduate School of Science, Kyoto University, Kitashirakawa-Oiwake-cho, Sakyo, Kyoto

8 606-8502, Japan

9 e-mail: kakioka@terra.zool.kyoto-u.ac.jp

T. Kokita

Department of Marine Bioscience, Fukui Prefectural University, 1-1 Gakuen-cho, Obama, Fukui

13 917-0003, Japan

14

S. Mori

Biological Laboratory, Gifu-Keizai University, 5-50 Kitagata, Ogaki, Gifu 503-8550, Japan

Corresponding author: Ryo Kakioka; Graduate School of Science, Kyoto University,

Kitashirakawa-Oiwake-cho, Sakyo, Kyoto, 606-8502 Japan; Tel.: +81-75-753-4077; Fax:

+81-75-753-4100; e-mail: kakioka@terra.zool.kyoto-u.ac.jp

21 
24 Abstract

25 The cyprinid species of the genus Gnathopogon, exhibiting flexible morphological and ecological variation, include limnetic life forms. We examined the origin of the limnetic forms and the population divergence of the Japanese Gnathopogon species, using molecular phylogenetic and phylogeographic analyses. A Bayesian phylogenetic inference approach based on mtDNA cytochrome $b$ sequence data revealed three major lineages in G. elongatus. One of them formed a monophyletic group with the limnetic species G. caerulescens, which is endemic to an ancient lake, Lake Biwa. The divergence of the G. caerulescens lineage was estimated to date back to the early Pleistocene. This precedes the formation of the extensive pelagic environment in the present Lake Biwa. However, the recent genetic divergence of G. caerulescens was inferred to originate in the present Lake Biwa in the late Pleistocene. Another lacustrine population in the Mikata Lakes was shown to belong to a different lineage from G. caerulescens. The majority of the population possessed unique, but non-monophyletic, haplotypes, suggesting a short evolutionary history. One of the cryptic lineages of G. elongatus discovered in the Ina Valley, the lower area of Lake Suwa, might be related to the extinct lacustrine subspecies G. elongatus suwae, which has been replaced by introduced congeners. The previous and ongoing introductions of Gnathopogon fishes would have produced genetic disturbance to the indigenous populations.

\section{Keywords}

Lacustrine form · Lake Biwa · Mikata Lakes · Lake Suwa · divergence time · Bayesian random local clock model 


\section{Introduction}

The family Cyprinidae is the most speciose group of freshwater fish. This group includes fishes with a highly diverse morphology, ecology, and physiology that are adapted to the vast range of habitats and resources they utilize (Winfield and Nelson 1991; Eschmeyer and Fricke 2011; Froese and Pauly 2011). The Gobioninae is a monophyletic group within the family (Tang et al. 2011), and, with rare exceptions, they primarily live on the bottom of streams. One such exception is the limnetic Gnathopogon caerulescens (Bănărescu and Nalbant 1973; Kotellat and Freyhof 2007). The genus Gnathopogon consists of nine species occurring in East Asia. The range of the genus includes the Russian Far East, China, the Korean Peninsula, and the Japanese Archipelago (Eschmeyer and Fricke 2011; Froese and Pauly 2011). Recent molecular phylogenetic studies (e.g., Yang et al. 2006; Saitoh et al. 2006, 2011; Mayden et al. 2009; Tang et al. 2011) consistently support the traditional taxonomic placement of Gnathopogon in the Gobioninae (e.g., Jordan and Fowler 1903; Bănărescu and Nalbant 1973), although in certain literature (e.g., Hosoya 1986, 1987, 2000) the genus is classified in the Barbinae based on its jaw structure. Two Gnathopogon species are endemic to Japan: Gnathopogon elongatus, found in the central to western regions of Honshu Island and Shikoku Island, and Gnathopogon caerulescens, which is endemic to Lake Biwa in central Honshu (Hosoya 2000, 2001).

Gnathopogon elongatus is a common and widespread species found in rivers and ponds. This species is also known to show substantial morphological variation in its swimming- and foraging-related apparatus (Hosoya 1987). In contrast, G. caerulescens is known to have a set of morphological features specialized to the limnetic lifestyle in Lake Biwa (e.g., a slender body, an upward-pointing mouth, and fine gill rakers; Hosoya 1987, 2000; Nakajima 1994). With its pelagic lifestyle, G. caerulescens has been hypothesized to be derived from G. elongatus, the morphologically flexible generalist species, and to have adapted to the extensive pelagic zone of Lake Biwa (Hosoya 1987; Nakajima 1994; Kawanabe 1996). Lake Biwa consists of a large, deep 
northern basin (surface area $617.8 \mathrm{~km}^{2}$; mean and maximum depths 43 and $103.6 \mathrm{~m}$, respectively) and a small, shallow southern basin (area $52.5 \mathrm{~km}^{2}$; mean and maximum depths 4 and $7 \mathrm{~m}$, respectively; see Fig. 1, inset). It is the largest lake in Japan and is well known as an ancient lake with a history of over 4 million years (Myr). However, the present northern basin, with its developed pelagic area, appeared at the most recent stage of the lake, approximately 0.4 million years ago (mya) (Yokoyama 1984; Kawabe 1989, 1994). Accordingly, G. caerulescens is hypothesized to have originated during the middle to late Pleistocene, after the development of the northern basin of Lake Biwa (Tomoda 1978; Nakajima 1994; Kawanabe 1996). This species has attracted attention as a typical case of adaptive speciation in a novel environment. Such adaptive speciation is also known from the divergences of the limnetic forms of sticklebacks or charrs in postglacial lakes (e.g., Schluter et al. 1992; Snorrason et al. 1992; Schluter 1998). The adaptation of Gnathopogon species to the pelagic environment has also been hypothesized in other lakes. The Mikata Lakes, located northwest of Lake Biwa, are inhabited by a G. caerulescens-like fish (Hosoya 1987). Their origin and relationship to G. caerulescens have not been clarified. Moreover, another Gnathopogon population presumably adapted to pelagic life, Gnathopogon elongatus suwae is known from Lake Suwa and Lake Kizaki, located in central Honshu (Jordan and Hubbs 1925). This fish is, however, believed to have become extinct during the 1960s.

It is probable that Gnathopogon includes several limnetic forms. The genus is a potential model system for the study of adaptive population divergence and speciation. However, no contemporary approaches (e.g., molecular phylogenetics and geometric morphometrics) have been applied to the study of the evolution of Gnathopogon fishes. Indeed, although Lake Biwa is the definitive example of an ancient lake in East Asia (Kawanabe 1996), studies based on contemporary approaches for other endemic animals and plants in Lake Biwa are lacking. An exception is a molecular phylogenetic study of the goby Gymnogobius isaza, which is endemic to Lake Biwa. The study suggested that this goby was derived from its amphidromous sister group in the late Pliocene, prior to the development of the vast, deep northern basin in the middle to late 
Pleistocene (Harada et al. 2002), despite this goby's present dependence on this environment in the northern basin.

The primary purpose of this study was to reveal the genetic relationships and divergence times among Japanese Gnathopogon species and regional populations, especially focusing on lacustrine populations. We used molecular phylogenetic and population genetic approaches with specimens collected from their entire native ranges in Japan. The nucleotide sequence of the mitochondrial cytochrome $b$ gene was used as the molecular marker because of the substantial accumulation of data in fishes. Based on the phylogeny, we examined the previous hypotheses on the origin and speciation of the limnetic forms of Japanese Gnathopogon.

\section{Materials and methods}

Specimen collection

The mtDNA sequence data were obtained from 513 specimens of Gnathopogon elongatus from 43 localities (locality code \#1-43) and 56 samples of G. caerulescens from four sites (\#44-47) in Lake Biwa (Table 1; Fig. 1). These samples included populations that have been affected by artificial introductions, as inferred from the mtDNA data and records of introductions by fishery activities (e.g., Takei 2007; Sakai 1995).

\section{Laboratory procedures and analyses}

The genetic divergence and population structure were evaluated using the nucleotide sequences of the 3'-half of the mitochondrial cytochrome $b$ gene [cyt $b$; 598 base pairs (bp); hereafter, the "short sequence"]. Nearly complete cyt $b$ sequences $(1,125 \mathrm{bp})$ were also determined for a number of the 
124 specimens $(n=16)$ to obtain more robust phylogenetic relationships (hereafter, the "long

125 sequence"; these haplotypes are denoted with an "L").

Total genomic DNA was isolated from fin clips preserved in $100 \%$ ethanol, using a

127 Genomic DNA Purification Kit (Promega, Madison, WI, USA). Polymerase chain reaction (PCR)

128 amplification was performed using the primer pair L14724 (5'-TGA CTT GAA RAA CCA YCG

129 YYG-3') (Palumbi et al. 1991) and H15915 (5'-ACC TCC GAT CTY CGG ATT ACA AGA C-3')

130 (Aoyama et al. 2000) to obtain the sequence of the entire cytb gene. The PCR conditions consisted

131 of 30 cycles of denaturation $\left(94^{\circ} \mathrm{C}, 15 \mathrm{~s}\right)$, annealing $\left(48^{\circ} \mathrm{C}, 15 \mathrm{~s}\right)$, and extension $\left(72^{\circ} \mathrm{C}, 30 \mathrm{~s}\right)$, using

132 a PC808 thermal cycler (ASTEC, Shime, Fukuoka, Japan). After purifying the PCR products by

133 treatment with ExoSAP-It (USB Corporation, Cleveland, $\mathrm{OH}, \mathrm{USA}$ ) at $37^{\circ} \mathrm{C}$, they were sequenced

134 using an automated DNA sequencer (ABI Prism GA310 or 3130xl; Applied Biosystems, Foster

135 City, CA, USA) with the above amplification primers and using a BigDye Terminator Cycle

136 Sequencing FS Ready Reaction Kit ver. 1.1 or 3.1 (Applied Biosystems). The obtained sequences

137 were deposited in DDBJ/GenBank/EMBL (accession numbers AB677321-AB677453). The

138 haplotype frequencies of each population were deposited in GEDIMAP

139 (http://gedimap.zool.kyoto-u.ac.jp; Watanabe et al. 2010) with population IDs P1382-P1428.

140 A phylogenetic analysis was conducted for two data sets of mtDNA, namely, the

141 short-sequence data for all of the specimens and the long-sequence data for selected specimens.

142 The latter were chosen to represent each of the lineages suggested by phylogenetic analysis with

143 the short sequences. For the former data, an unrooted tree was reconstructed by the

144 neighbor-joining algorithm (NJ; Saitou and Nei 1987) using PAUP*4.0b10 (Swofford 2002). The

145 genetic distances were calculated under a TIM + G model selected by Akaike's information

146 criterion (AIC), as implemented in Modeltest 3.7 (Posada and Crandall 1998). The robustness of

147 the NJ tree was assessed using the bootstrap method (BP) with 1,000 replicates by PAUP*. In

148 addition, statistically parsimonious networks were constructed using TCS 1.2.1 (Clement et al.

149 2000). There were no insertions/deletions in our dataset. 
For the long-sequence data set, the cyt $b$ sequences of three congeneric species,

151 Gnathopogon nicholsi (AY952997), Gnathopogon imberbis (AY952998), and Gnathopogon

152

153

154

155

156

157

158

159

160

161

162

163

164

165

166

167

168

169

170

171

172

173

174

175

strigatus (AY952999; referred to as Paraleucogobio strigatus), all reported by Yang et al. (2006),

were used as the outgroup. In addition, the sequences of Sarcocheilichthys variegatus microoculus (AB054124; Saitoh et al. 2003), Pseudorasbora parva (AB677449; this study), Pseudorasbora pumila pumila (AB677452, AB677453; this study), and Pseudorasbora pumila subsp. (sensu Hosoya 2000; AB677450, AB677451; this study) were used as the outgroup of Gnathopogon species, because they are all included in the tribe Sarcocheilichthyini in the Gobioninae, together with Gnathopogon (Tang et al. 2011). The evolutionary genetic distance and the maximum likelihood (ML) tree were estimated using PAUP* with the GTR + G + I model selected by AIC, implemented in Modeltest. The robustness of the ML tree was assessed using the BP with 500 replicates.

A Bayesian approach was used to estimate the phylogenetic tree for the long-sequence data set and the divergence times of lineages with the GTR + G + I models and the Yule (speciation) tree prior using BEAST v1.6.2 (Drummond and Rambaut 2007). We adopted the random local clock model, which assumes one or more independent rates on different branches (Drummond and Suchard 2010). To estimate the time of the most recent common ancestors (tMRCA), two constraints on the node ages were applied. First, the uplift of the Central Highland of Honshu Island in the Pliocene-early Pleistocene (Yonekura et al. 2001; Machida et al. 2006) is thought to have caused the divergence between two Pseudorasbora pumila subspecies (outgroup), which show a vicariant distribution in the eastern (P. pumila pumila) and western (P. pumila subsp.) areas across the highland (Watanabe et al. 2000). The highland, or the great valley (Fossa Magna) within the highland, represents one of the most important geographic barriers for freshwater fish fauna in Japan (see Watanabe 2010). The node of the MRCA of those subspecies was constrained following a lognormal prior distribution, ranging from approximately 2 to 5 mya $[$ mean $=3.5$ mya, $\log (\mathrm{SD})=0.3$, offset $=0]$. We found a distinct lineage in the upper region of the 
176 Tenryu River system (Ina Valley, Loc. \# 2, 3; see "Results"). Therefore, as the second constraint,

177 the isolation of the lineage is thought to have occurred with or preceded the uplift of the Kiso and

178 Akaishi Mountains, which formed the valley in the middle to early Pleistocene (ca. 0.8 mya;

179 Matsushima 1995; Moriyama 2001). The constraint was specified as an inverse-gamma prior

180 distribution, with the shape parameter $=2$, scale $=3$, and offset $=0$. Both of the prior distributions

181 for the node ages involve a wide range. Therefore, they should act only as lax constraints for

182 determining the tMRCA and give conservative results. All of the other model parameters used

183 default priors. For each Markov Chain Monte Carlo (MCMC) analysis, we performed two

184 independent runs of 50 million generations. We sampled every 1,000th generation and removed

$18510 \%$ of the initial samples as burn-in. The convergence of the chains to the stationary distribution

186 was confirmed using Tracer v1.5 (Rambaut and Drummond 2009). The consensus tree was

187 calculated by TreeAnnotator v.1.6.1 in the BEAST package, and the tree was visualized using

188 FigTree v1.3.1 (Rambaut 2009).

To describe the genetic diversity of each population, the following indices were

190 calculated, based on the short-sequence data set using ARLEQUIN 3.5 (Excoffier and Lischer

191 2010): the number of haplotypes $(A)$, the haplotype diversity $(h)$, and the nucleotide diversity $(\pi)$.

192 To estimate the demographic history of G. caerulescens, we applied a Bayesian skyline plot (BSP)

193 analysis (Drummond et al. 2005), implemented in BEAST. We used the short-sequence data of $G$.

194 caerulescens $(n=54)$ with several related haplotypes of $G$. elongatus $(n=5)$ as the outgroup, and

195 performed two independent runs with an MCMC chain length of 50 million generations. We

196 sampled every 1,000th generation and removed $10 \%$ of the initial samples as burn-in. The

197 substitution model used was HKY + I, selected by Modeltest, and the time to expansion was

198 estimated using the mutation rate obtained in the above Bayesian phylogenetic analysis with the

199 long-sequence data [lognormal prior distribution, mean $=0.0183 / \mathrm{Myr}, \log (\mathrm{SD})=0.5$, covering

$200 \quad 0.0070-0.0368 / \mathrm{Myr}$ in the 95\% range; see the Results]. The BSP result with the stepwise

201 (constant) model was summarized using Tracer. In addition, we conducted neutrality tests by 
202 calculating Tajima's $D$ (Tajima 1989) and Fu's $F_{S}(\mathrm{Fu} 1997)$ for the same dataset to explore its 203 demographic change, using ARLEQUIN 3.5. The significance for the estimates was tested by 20410,000 permutations.

\section{Results}

Divergence of Gnathopogon and distribution

A total of 112 haplotypes of the short sequences were obtained from Japanese Gnathopogon fishes.

212 The mtDNA phylogeny revealed two major lineages in these sequences, with substantial

213 divergence between the two lineages $[0.077 \pm 0.004$ (mean \pm standard deviation) in uncorrected $p$ distance, and $0.109 \pm 0.009$ in GTR + I + G distance for the 1,125-bp data set; Figs. 2, 3, 4; Table 2]. One lineage, with 72 haplotypes, included clade C (23 haplotypes) corresponding to $G$. caerulescens, and clade E1 (49 haplotypes) consisting of haplotypes primarily from the Lake Biwa area and the western ranges of G. elongatus (Fig. 3). The other major lineage, with 40 haplotypes, consisted of haplotypes obtained from the eastern populations of G. elongatus and was divided into two sub-lineages. One of these sub-lineages consisted of widely distributed haplotypes (E2; 33 haplotypes; Fig. 3). The distribution of haplotypes belonging to the other sub-lineage was restricted to the upper region of the Tenryu River (Ina Valley), flowing from Lake Suwa, central Honshu (E3; 7 haplotypes; Loc. \#1, \#2) (Table 1; Figs. 1, 3). Overall, the mtDNA phylogeny indicated that G. elongatus consists of paraphyletic lineages with allopatric distribution, one of which is more closely related to the limnetic species G. caerulescens. 
one exception that showed both types (Loc. \#24). The E2 haplotypes (the majority in this area) were identical to or very close to those detected in the Ise Bay area beyond the Suzuka Mountains. Certain populations with E2 haplotypes in the Lake Biwa area exhibited a low genetic diversity (Table 1) and were sporadically distributed in the network (closed circles in Fig. 2). Some haplotypes exhibited irregular geographical distributions. For example, the haplotypes of clades C and E1 were found in Lake Suwa (Loc. \#1; Fig. 3), which was consistent with the documented introductions of G. caerulescens stocks putatively from Lake Biwa into Lake Suwa (Kurasawa et al. 1981). A number of haplotypes, such as haplotypes e1-01 and e1-17 of clade E1, were detected from dispersed sites (Fig. 3) [see Electronic Supplementary Material (ESM) Appendix Table S1], another indication of their artificial distribution.

Genetic characteristics of limnetic forms

The clade C haplotypes were found almost exclusively from G. caerulescens in Lake Biwa (and Lake Suwa, via introduction). Exceptionally, two clade C haplotypes were detected in the $G$. elongatus populations around Lake Biwa at a low frequency (1.6\%; 2 of 125 specimens).

Conversely, a clade E2 haplotype (e2-01) was found in G. caerulescens (3.6\%; 2 of 56). In contrast, another known extant lacustrine population from the Mikata Lakes possessed the non-monophyletic haplotypes included in clade E1 (star symbol in Fig. 2). The majority of the haplotypes are, however, relatively close to each other, except for haplotype e1-01, which is widely distributed.

As mentioned above, we did not find any unique haplotypes from Lake Suwa and its inlets, the type locality of the "extinct" G. elongatus suwae. However, haplotypes of the distinct clade (E3) were found exclusively from the tributaries of the outlet of the lake. In one of their two localities (Loc. \#2), the clade E3 haplotypes co-occurred with the clade E1 haplotypes commonly found around Lake Biwa. 
255 Divergence time

The number of changes in the substitution rate across the phylogeny was inferred to be $1.17 \pm 0.02$

times from the random local clock model. This value corresponded to a slightly slower rate in the

Japanese Gnathopogon clade (0.0164-0.0195/Myr) than in the other clades (0.0243-0.0251/Myr)

(Fig. 4; Table 2), but the difference was not drastic.

lineage leading to clades C (G. caerulescens) and E1 was inferred as $1.68 \mathrm{Myr}(0.47-3.53 \mathrm{Myr})$,

comparable with that of E2 and E3 (1.88 Myr; 0.62-3.83 Myr). These age estimates were smaller

than the tMRCA of Pseudorasbora pumila subspp., which was assumed to correspond to the Fossa

Magna vicariance, inferred as 2.53 Myr (1.28-4.01 Myr).

limnetic species began 0.05 mya (Fig. 5). Neutrality tests also indicated a population expansion

(Tajima's $D=-1.75, p=0.020 ;$ Fu's $F_{S}=-7.99, p=0.001$ ).

\section{Discussion}

Credibility of mutation rate and divergence time estimates

The mutation rate of the mtDNA cytochrome $b$ gene for the Japanese Gnathopogon fishes was estimated to be $0.016-0.025 / \mathrm{Myr} /$ lineage for GTR $+\mathrm{I}+\mathrm{G}$ distances. This rate appears to be faster 
et al. 2008; Watanabe and Takahashi 2010). However, many of previous studies estimated mutation rates simply using the proportion of sequence differences ( $p$ distance), while we estimated them based on a molecular evolutionary model $(G T R+I+G)$. Indeed, the mutation rates based on $p$ distance were estimated for our data at $0.007-0.015 / \mathrm{Myr} /$ lineage (see Table 2 for the major clades), which agree with those from previous studies.

The credibility intervals of the tMRCA estimates were generally large because of the lax constraints used in dating the phylogeny. Also, our estimation of tMRCAs might be biased because it was based on single mtDNA gene sequences. However, because the phylogenic tree used for the analyses had high statistical support, we here consider that the estimates can be used as conservative values for a discussion of the population divergence and origin of limnetic forms in Gnathopogon fishes. The estimations need to be tested in the future with increased data, especially multilocus nuclear sequences, and with denser taxon sampling.

\section{Cryptic differentiation within Gnathopogon elongatus}

Monophyly of G. elongatus was not supported by our phylogenetic analyses. This species included two deeply diverged cryptic lineages, one of which is closer to G. caerulescens than to the other. The Suzuka Mountains roughly bounded the two lineages to the east and west. The Suzuka Mountains are known as one of the major geographical boundaries of freshwater fish fauna in Japan (Watanabe 1998, 2010), which started uplifting during the early Pleistocene (Yokoyama 1988; Kawabe 1994).

The eastern lineage was further divided into two allopatrically distributed sub-lineages, E2 and E3. Clade E2 was found across a widespread area, while E3 was restricted to the upper reaches of the Tenryu River in Ina Valley flowing from Lake Suwa. The Bayesian tMRCA analysis for E2 and E3 yielded an estimation of 1.88 Myr (0.62-3.83 Myr, 95\% HPD), which tends to precede the uplift of the Kiso Mountains ( 0.8 mya) used as a calibrating point. The wide 
credibility interval may prevent ruling out the vicariance by the uplift of the Kiso Mountains, but the preceding geological events, such as the formation of Ina Valley ( 2 mya; Machida et al. 2006), could have caused the divergence between E2 and E3.

The distribution range and genetic distinctness of E3 suggest that this mtDNA lineage may be related to the "extinct" G. elongatus suwae, which was the local representative in an area around Lake Suwa (Jordan and Hubbs 1925; Miyadi 1930). In other words, we may have discovered an unknown lineage of G. elongatus closely related to G. elongatus suwae, or rediscovered this subspecies itself. G. elongatus suwae was described from lacustrine populations; therefore, detailed morphological comparisons are necessary to determine the taxonomic status of the present populations from creeks in the Ina Valley.

We showed that $G$. elongatus is a paraphyletic species. In addition, the type locality of $G$. elongatus is unspecified (Temminck and Schlegel 1846). All three lineages (E1, E2, and E3) of this species should be taxonomically re-examined through detailed morphological comparisons, including inspection of the type series of this group.

Origins of limnetic forms

Adaptive divergence in an ancient lake is usually considered to begin with the invasion of a new habitat, followed by ecological adaptations to novel environments, and the derivation of new taxa from the ancestors (Martens 1997; Kornfield and Smith 2000; Kontula et al. 2003). This process of adaptive evolution has been hypothesized for the origin of some endemic species of Lake Biwa (e.g., Tomoda 1978; Tokui and Kawanabe 1984; Kawanabe 1996; Yuma et al. 1998). The endemic species of Lake Biwa are often divided into two categories, namely, "relic species" and "species evolved in the lake" (Kawanabe 1978, 1996). Particularly for the latter, their origins have been presumed to be the ancestral species occurring around the lake following adaptation to novel environments (e.g., the extensive pelagic area of the northern basin and the locally developed 
rocky shores). Such environments developed after the middle Pleistocene (ca. 0.4 mya or later; Yokoyama 1984; Meyers et al. 1993); therefore, the species that evolved in the lake are believed to have originated in the same or later periods (e.g., Takahashi 1989). Indeed, the Lake Biwa endemic gudgeon, Sarcocheilichthys, exhibits clear trophic-resource polymorphism but shows no genetic divergence between morphs. These characteristics suggest a recent origin of the adaptive population divergence (Komiya et al. 2011).

However, our results suggest that such recent speciation does not hold for G. caerulescens. This species has been considered as a typical species that evolved in Lake Biwa from the riverine ancestor (G. elongatus) after the establishment of the present Lake Biwa (Hosoya 1987; Nakajima 1994; Kawanabe 1996) because G. caerulescens is specialized in feeding apparatus for planktivory (e.g., an upward-directed mouth and 13-20 gill rakers vs. subterminal mouth and 6-12 gill rakers in G. elongatus) and body shape for efficient swimming in open water (e.g., a low body depth and caudal peduncle; Hosoya 1987, 2000). However, the estimated tMRCA of G. caerulescens and E1 of G. elongatus indicated that their divergence dates to the early Pleistocene (1.68 Myr; 0.47-3.53 Myr, 95\% HPD). Even with the wide credibility interval, it is unlikely that the G. caerulescens lineage derived at 0.4 mya or more recently. Molecular phylogenetic studies have also suggested an earlier origin (Late Pliocene) for the Lake Biwa pelagic goby, Gymnogobius isaza (Harada et al. 2002), which was similarly presumed to have evolved in the present Lake Biwa (Takahashi 1989; Kawanabe 1996).

In contrast, the tMRCA and BSP analyses focused on G. caerulescens suggested a more recent beginning of diversification in the present mtDNA lineage $(0.23$ mya) and a population expansion in the late Pleistocene (0.05 mya). These results agree well with the expected scenario in which G. caerulescens has thrived in the present environment of Lake Biwa. The adaptation to the limnetic lifestyle with the acquisition of specialized morphological features probably enabled its population expansion in the lake. It remains possible, however, that limnetic features had evolved in an extinct lake at the earlier stage of Paleo-Lake Biwa, and were retained as standing 
variation in the populations having survived in rivers or marshes.

Our data clearly rejected the monophyletic origin of G. caerulescens and another lacustrine population in the Mikata Lakes. Most of the mtDNA haplotypes in the Mikata Lakes were endemic and close to each other, but were not monophyletic. The morphological specialization of the Mikata Lakes population to pelagic life is considered to be limited (Hosoya 1987). These findings suggest a short evolutionary history of the population in the lakes and/or confined adaptation to the less-developed pelagic environment in the lakes. These circumstances might have allowed gene flow with neighboring populations in their inlets. These hypotheses are supported by the geological history of the Mikata Lakes. The lakes have a relatively long history of at least 0.1 Myr (Takemura et al. 1994), but all the lakes, except one, are saline or brackish at present. Moreover, the freshwater lake has experienced seawater incursions during periods of high sea level because of their low altitude ( $0 \mathrm{~m}$ above sea level).

Our results and a previous report (Hosoya 2003) strongly suggest that G. elongatus suwae in Lake Suwa has been extirpated from the lake. The extinction of this population is considered to have resulted from habitat degradation and the hybridization with introduced G. caerulescens (and possibly G. elongatus) since 1925 (Kurasawa et al. 1981; Hosoya 1997, 2003; Takei 2007).

Another known population of G. elongatus suwae from Lake Kizaki (60 km north of Lake Suwa) is also suggested to have become extinct through a similar process (Kohno et al. 2006). Lake Suwa was formed in the early (1.5-1.2 mya) or middle (0.2 mya) Pleistocene (see Machida et al. 2006). In this long-standing lake, G. elongatus suwae might have evolved adapting to the lacustrine environment as in other limnetic populations.

The present study provided phylogenetic evidence for the multiple origins of the limnetic forms of Gnathopogon fishes. Pelagic adaptation should have required a series of novel morphological, physiological, and ecological traits. In addition to the morphological variability of G. elongatus, which might serve as a preadaptation (Hosoya 1987), the variety furnished by the long-standing lineages might have contributed to the evolution of pelagic forms in this genus. 
385 Natural and artificial hybridization

We found a low-level ( 2\%) of mtDNA introgression in both directions between G. caerulescens and G. elongatus. Although they generally show a parapatric distribution in and around Lake Biwa, they may have the chance to hybridize, because they produce fertile offspring and share spawning sites (i.e. emergent plants at the lakeshore, lagoons and inlets; Nakamura 1969). Indeed, hybrid offspring have been found near the spawning sites at low frequency (Kokita, unpublished data). A hybrid disadvantage may serve to effectively prevent introgression between them in the natural habitats, because their lifestyles (entirely pelagic vs. benthopelagic) substantially differ. For several decades, Gnathopogon fishes have been intensively introduced to establish fisheries (Nakamura 1969; Biodiversity Center of Japan 2002). Moreover, G. elongatus may have been transplanted accidentally via contaminations to the stocks of, for example, the crucian carp

Carassius cuvieri and the common carp Cyprinus carpio, which are commonly stocked for fishery and game fishing from ponds sometimes inhabited by G. elongatus (Okada and Nakamura 1948; Yada 1977). Widespread introductions of Gnathopogon fishes may have affected the native fish assemblages and native populations of Gnathopogon fishes. Some of the E1 haplotypes were distributed widely from Lake Suwa to southwestern Shikoku Island. It is believed that the native range of G. elongatus includes southwestern Shikoku Island (Hosoya 2001; Biodiversity Center of Japan 2002). However, we found only a single widespread E1 haplotype in four localities in this area. Similarly, on the eastern side of Lake Biwa, several E2 haplotypes were shared with populations in the Ise Bay basin beyond the Suzuka Mountains. The presence of widespread haplotypes that cross known biogeographic boundaries (Watanabe et al. 2010) strongly suggests that Gnathopogon populations have been established in many localities out of their original ranges. In addition, hybridization or replacement of the native Gnathopogon fish with introduced fish is probable. Gnathopogon caerulescens and G. elongatus are known to form a hybrid swarm in a 
410 nonnative habitat, despite their reproductive isolation in their native habitat (Sakai 1995). As

411 mentioned above for G. elongtus suwae, artificial introductions would result in losses of endemic 412 lineages and, hence, a reduction in the biodiversity of natural communities.

413 


\section{Acknowledgments}

415 We are very grateful to T. Abe, T. Asaka, T. Karube, K. Kodama, T. Komiya, H. Kumada, T. Mukai,

416 H. Ogawa, H. Sakai, M. Sugimura, N. Suzuki, and K. Tominaga for providing a portion of

417 specimen, M. Nishida for lending us experimental instruments, and K. Hosoya for giving us

418 valuable information. This study was partly supported by Grants-in-Aid from the Ministry of

419 Education, Culture, Sports, Science and Technology of Japan (nos. 18570086, 21370035, and

420 2155282, and "Formation of a Strategic Base for Biodiversity and Evolutionary Research: from

421 Genome to Ecosystem" of the GCOE).

422 


\section{References}

Aoyama J, Watanabe S, Ishikawa S, Nishida M, Tsukamoto K (2000) Are morphological characters distinctive enough to discriminate between two species of freshwater eels, Anguilla celebesensis and A. interioris? Ichthyol Res 47:157-161

Bănărescu P, Nalbant TT (1973) Pisces, Teleostei, Cyprinidae (Gobioninae). Das Tierreich, Lieferung 93. Walter de Guryter, Berlin

Biodiversity Center of Japan (2002) The national survey on the natural environment report of the distributional survey of Japanese animals (freshwater fishes). Japan Wildlife Research Center, Tokyo (in Japanese)

Burridge, CP, Craw D, Fletcher D, Waters JM (2008) Geological dates and molecular rates: fish DNA sheds light on time dependency. Mol Biol Evol 25:624-633

Clement M, Posada D, Crandall KA (2000) TCS: a computer program to estimate gene genealogies. Mol Ecol 9:1657-1660

Drummond AJ, Rambaut A (2007) BEAST: Bayesian evolutionary analysis by sampling trees. BMC Evol Biol 7:214

Drummond AJ, Suchard MA (2010) Bayesian random local clocks, or one rate to rule them all. BMC Biol 8:114

Drummond AJ, Rambaut A, Shapiro B, Pybus OG (2005) Bayesian coalescent inference of past population dynamics from molecular sequences. Mol Biol Evol 22: 1185-1192

Eschmeyer WN, Fricke R. (2011) Catalog of Fishes electronic (version 5 May 2011). http://research.calacademy.org/ichthyology/catalog/fishcatmain.asp. Accessed 20 May 2011

Excoffier L, Lischer H E L (2010) Arlequin suite ver 3.5: a new series of programs to perform population genetics analyses under Linux and Windows. Mol Ecol Resour 10:564-567

Froese R, Pauly D (2011) FishBase. World Wide Web electronic publication.http://www.fishbase.org. version 2011/2. Accessed 20 May 2011 
449 Fu YX (1997) Statistical tests of neutrality of mutations against population growth, hitchhiking, and background selection. Genetics 147:915-925

451 Fujioka Y (2001) Thermolabile sex determination in honmoroko. J Fish Biol 59:851-861

452 Fujioka Y (2006) Patterns of sex ratio response to water temperature during sex determination in honmoroko Gnathopogon caerulescens. Fish Sci 72:1034-1041

Harada S, Jeon SR, Kinoshita I, Tanaka M, Nishida M (2002) Phylogenetic relationships of four species of floating gobies (Gymnogobius) as inferred from partial mitochondrial cytochrome $b$ gene sequences. Ichthyol Res 49:324-332

Hosoya K (1986) Interrelationships of the Gobioninae (Cyprinidae). In: Uyeno T, Arai R, Taniuchi T, Matsuura K (eds) Indo-Pacific Fish Biology: Proceeding of the Second International Conference on Indo-Pacific Fishes. Ichthyological Society of Japan, Tokyo, pp 484-501

Hosoya K (1987) Phylogeny and character displacement in Gnathopogon fishes. In: Mizuno N, Goto A (eds) Freshwater fishes in Japan: their distribution, variation and speciation. Tokai University Press, Tokyo, pp 31-40 (in Japanese)

Hosoya K (1997) The endangered Japanese freshwater fishes. In: Nagata Y, Hosoya K (eds) Circumstances in endangered Japanese freshwater fishes and their protection. Midori Shobo, Tokyo, pp 3-21 (in Japanese)

Hosoya K (2000) Cyprinidae. In: Nakabo T (ed) Fishes of Japan with pictorial keys to the species, 2nd edn. Tokai University Press, Tokyo, pp 253-271 (in Japanese)

Hosoya K (2001) Gnathopogon. In: Kawanabe H, Mizuno N, Hosoya K (eds) Freshwater fishes of Japan 3rd edn Yama-Kei Publishers, Tokyo, pp 297-299 (in Japanese)

Hosoya K (2003) Gnathopogon elongatus suwae. In: Japan Ministry of the Environment (ed) Threatened Wildlife of Japan, Red Data Book. 2nd ed. Japan Wildlife Research Center, Tokyo, pp 26-27 (in Japanese) 
475 Jordan DS, Hubbs CL (1925) Record of fishes obtained by David Starr Jordan in Japan, 1922.

Mem Carneg Mus10:93-346

477 Kawabe T (1989) Stratigraphy of the lower part of the Kobiwako group around the Ueno Basin,

Kawabe T (1994) Chapter 1. Biwako no Oitachi (formation of Lake Biwa). In: Research Group for Natural History of Lake Biwa (ed) Biwako no Shizenshi (The natural history of Lake Biwa). Yasaka Shobo, Tokyo, pp 24-72 (in Japanese)

Kawanabe H (1978) Some biological problems. Verh Internat Ver Limnol 20:2674-2677

Kawanabe H (1996) Asian great lakes, especially Lake Biwa. Environ Biol Fish 47:219-234

Kohno N, Hosoe A, Ogawa S (2006) Species composition of fish caught by shore seine in Lake Kizaki. Bull Nagano Pref Fish Exp Stn 8:35-38 (in Japanese)

Komiya T, Fujita S, Watanabe K (2011) A novel resource polymorphism in fish, driven by differential bottom environments: an example from an ancient lake in Japan. PLoS ONE 6: $\mathrm{e} 17430$

Kontula T, Kirilchik SV, Vainola R (2003) Endemic diversification of the monophyletic cottoid fish species flock in Lake Baikal explored with mtDNA sequencing. Mol Phylogenetics Evol 58:142-147

Kornfield I, Smith PF (2000) African cichlid fishes: model systems for evolutionary biology. Annu Rev Ecol Syst 31:163-96

Kottelat M, Freyhof J (2007) Gobioninae. In: Kottelat M, Freyhof J (ed) Handbook of European Freshwater Fishes. Publications Kottelat, Cornol, pp 85-108.

Kurasawa H, Yamamoto M, Okino T (1981) Chronological changes of fish and mollusca faunae and transplantation species in Lake Suwa. Ann Environ Sci Shinshu Univ 3:1-6 (in Japanese)

Machida H, Matsuda T, Umitsu M, Koizumi T (2006) Regional geomorphology of the Japanese Islands, vol 5: Geomorphology of Chubu. University of Tokyo Press, Tokyo (in Japanese)

500 Martens K (1997) Speciation in ancient lakes. Trends Ecol Evol 12:177-182. 
501 Matsushima S (1995) Morphogenetic history of the Ina basin. Res Rep Iida City Mus 3:1-145 (in $502 \quad$ Japanese with English abstract)

503 Mayden RL, Chen WJ, Bart HL, Doosey MH, Simons AM, Tang KL, Wood RM, Agnew MK, 504 Yang L, Hirt MV, Clements MD, Saitoh K, Sado T, Miya M, Nishida M (2009) Reconstructing 505 the phylogenetic relationships of the earth's most diverse clade of freshwater fishes—order 506 Cypriniformes (Actinopterygii: Ostariophysi): A case study using multiple nuclear loci and 507 508 the mitochondrial genome. Mol Phylogenet Evol 51:500-514

Meyers PA, Takemura K, Horie S (1993) Reinterpretation of late Quaternary sediment chronology of Lake Biwa, Japan, from correlation with marine glacial-interglacial cycles. Quat Res $39: 154-162$

Miyadi D (1930) Kizaki-Ko no gyorui ni tsuite (On fishes of Lake Kizaki). In: Tanaka A (ed) Nippon Kita-Alps Kosho no Kenkyu (Studies on the lakes of Japanese Northern Alps). Shinano Kyoiku-Kai Kitaazumi Bukai, Omachi, pp 626-630 (in Japanese)

Moriyama A (2001) Chronology of mountain formation in the Central Mountain region in Japan. In: Yonekura N, Okada A, Moriyama A (eds) Hendou Chikeigaku (Techtonic geomorphology). Kokinshoin, Tokyo, pp 87-109 (in Japanese)

Nakajima T (1994) Chapter 4-d. Cyprinid fishes. In: Research Group for Natural History of Lake Biwa (ed) Biwako no Shizenshi (The natural history of Lake Biwa), Yasaka Shobo, Tokyo, pp 235-275 (in Japanese)

Nakamura M (1969) Cyprinid Fishes of Japan. Spec Publ Res Inst Nat Resour, Tokyo (in Japanese)

Okada Y, Nakamura M (1948) Zoshoku (Aquaculture). In: Nippon no Tansui-Gyorui (Freshwater fishes of Japan), Nippon Shuppan-sha, Osaka, pp 119-125 (in Japanese) Guide to PCR. University of Hawaii, Honolulu 
528 Rambaut A, Drummond AJ (2009) Tracer Version 1.5. http://tree.bio.ed.ac.uk/software/tracer/

529 Rambaut A (2009) FigTree Version 1.3.1. http://tree.bio.ed.ac.uk/software/figtree/

530 Saitoh K, Sado T, Mayden RL, Hanzawa N, Nakamura K, Nishida M, Miya M (2006)

531 Mitogenomic evolution and interrelationships of the Cypriniformes (Actinopterygii:

532 Ostariophysi): The first evidence towards resolution of higher-level relationships of the world.

$533 \quad$ J Mol Evol 63:826-841

534 Saitoh K, Sado T, Doosey MH, Bart Jr HL, Inoue JG, Nishida M, Mayden RL, Miya M (2011)

535 Evidence from mitochondrial genomics supports the lower Mesozoic of South Asia as the

536 time and place of basal divergence of cypriniform fishes (Actinopterygii: Ostariophysi). Zool

$537 \quad$ J Linn Soc 161:633-662

538 Saitou N, Nei M (1987) The neighbor-joining method: a new method for reconstructing

539 phylogenetic trees. Mol Biol Evol 4:406-425

540 Sakai H (1995) Natural hybrid and speciation in fish. Biol Sci 47:113-123 (In Japanese)

541 Schluter D, McPhail, JD (1992) Ecological character displacement and speciation in sticklebacks.

$542 \quad$ Am Nat 140:85-108

543 Schluter D (1998) Ecological speciation in postglacial fishes. In: Grant PR (ed) Evolution on $544 \quad$ islands. Oxford University Press, Oxford

545 Snorrason SS, Skúlason S, Jonsson B, Malmquist HJ, Jónasson PM, Sandlund OT, Lindem T

546 (1992) Trophic specialization in Arctic charr Salvelinus alpinus (Pisces; Salmonidae):

547 morphological divergence and ontogenetic niche shifts. Biol J Linn Soc 52:1-18

548 Swofford DL (2002) PAUP*: phylogenetic analysis using parsimony (*and other methods), ver 4.

$549 \quad$ Sinauer Associates, Sunderland

550 Tajima F (1989) Statistical method for testing the neutral mutation hypothesis by DNA

$551 \quad$ polymorphism. Genetics $123: 585-595$

552 Takahashi S (1989) A review of the origins of endemic species in Lake Biwa with special reference 
to the goby fish, Chaenogobius isaza. J Paleolimnology 1:279-292

554 Takei K (2007) Verified the list of the fishes of Lake Suwa. Bull Nagano Pref Fish Exp Stn 9:7-21 (in Japanese)

Takemura K, Kitagawa H, Hayashida A, Yasuda Y (1994) Sedimentary facies and chronology of core samples from Lake Mikata, Lake Suigetsu and Kurota Lowland, central Japan—sedimentary environment in Mikata Lowland since the last interglacial time. J Geography 103:233-242

Tang KL, Agnew MK, Chen WJ, Vincent Hirt M, Raley ME, Sado T, Schneider LM, Yang L, Bart of the gudgeons (Teleostei: Cyprinidae: Gobioninae). Mol Phylogenet Evol 61:103-124

Temminck CJ, Schlegel H (1846) Pisces. Fauna Japonica, sive descriptio animalium quae in itinere per Japoniam suscepto annis 1823-30 collegit, notis observationibus et adumbrationibus illustravit P. F. de Siebold. Parts 10-14:173-269

Tokui T, Kawanabe H (1984) Fishes. In: Horie S (ed) Lake Biwa, Monographiae Biologicae (volume 54). Dr W Junk Publishers, Dordrecht, pp 339-360

Tomoda Y (1978) Biwako to Namazu (Lake Biwa and catfish). Chobunsha, Tokyo (in Japanese)

Watanabe K (1998) Parsimony analysis of the distribution pattern of Japanese primary freshwater fishes, and its application to the distribution of the bagrid catfishes. Ichthyol Res 45:259-270

Watanabe K (2010) Faunal structure of Japanese freshwater fishes and its artificial disturbance. Environ Biol Fish. Doi:10.1007/s10641-010-9601-5

Watanabe K, Takahashi H (2010) Tansuigyorui chiri no shizenshi (Natural history of freshwater fish geography). Hokkaido University Press, Sapporo (in Japanese)

Watanabe K, Iguchi K, Hosoya K, Nishida M (2000) Phylogenetic relationships of the Japanese minnows, Pseudorasbora (Cyprinidae), as inferred from mitochondrial 16S rRNA gene sequences. Ichthyol Res 47:43-50

578 Watanabe K, Kano Y, Takahashi H, Mukai T, Kakioka R, Tominaga K (2010) GEDIMAP: a 
database of genetic diversity for Japanese freshwater fishes. Ichthyol Res 57:107-109

580 Winfield IJ, Nelson JS (1991) Cyprinid Fishes: Systematics, biology and exploitation. Chapman \& Hall, London.

Yada T (1977) Studies on the spawning period and number of egg spawned on "Tamoroko", Japanese)

Yang JQ, He SP, Freyhof J, Witte K, Liu HZ (2006) The phylogenetic relationships of the Hydrobiologia 553:255-266

Yokoyama T (1984) Stratigraphy of the Quaternary system around Lake Biwa and geohistory of the ancient Lake Biwa. In: Horie S (ed) Lake Biwa, Monographiae Biologicae (volume 54). Dr W Junk Publishers, Dordrecht, pp 43-128

Yokoyama T (1988) Seinan Nihon no Shizenshi (Natural history of southwestern Japan). Sanwa-shobo, Kyoto (in Japanese)

593 Yonekura N, Kaizuka S, Nogami M, Chinzai K (2001) Regional geomorphology of the Japanese 594 Islands, vol 1: Introduction to Japanese geomorphology. University of Tokyo Press, Tokyo (in $595 \quad$ Japanese)

596 Yuma H, Hosoya K, Nagata Y (1998) Distribution of the freshwater fishes of Japan: an historical overview. Environ Biol Fish 52:97-124 
600

601 Fig. 1 Sampling localities for Gnathopogon fishes. Numbers correspond to those in Table 1.

602 Larger ellipses indicate the inclusion of several neighboring sites

603

Fig. 2 Unrooted neighbor-joining (NJ) tree of Japanese Gnathopogon fishes based on the 3'-half of mtDNA cytochrome $b$ sequences (598 bp). The evolutionary distance is based on the TIM $+\mathrm{G}$ model selected by AIC, with base frequencies of $\mathrm{A}=0.292, \mathrm{C}=0.149, \mathrm{G}=0.284$, and $\mathrm{T}=0.275$, a substitution rate matrix of $\mathrm{A} \leftrightarrow \mathrm{C}=1.000, \mathrm{~A} \leftrightarrow \mathrm{G}=19.846, \mathrm{~A} \leftrightarrow \mathrm{T}$ and $\mathrm{C} \leftrightarrow \mathrm{G}=2.182$, and $\mathrm{C} \leftrightarrow$ $\mathrm{T}=34.975$, and a gamma shape $=0.263$. The region where each haplotype was detected is shown by a different symbol. Numbers at nodes indicate NJ bootstrap probabilities (values $<70 \%$ not 610 shown)

Fig. 3 Geographic distributions and statistically parsimonious networks for the haplotypes of each Gnathopogon lineage in Japan. Areas of nodes in the networks are proportional to haplotype

614 frequency; different patterns indicate geographic origins of a haplotype. Filled squares indicate 615 unobserved hypothetical haplotypes. The sampling site where each lineage was detected is shown by a symbol according to a geographic region

Fig. 4 Bayesian phylogenetic tree of the Japanese Gnathopogon fishes with selected continental species and outgroup based on the mtDNA cytochrome $b$ sequences $(1,125 \mathrm{bp})$ with the GTR $+\mathrm{I}+$ $\mathrm{G}$ model. The tree is dated by the random local clock model with two node-age constraints $(\mathrm{C} 1$ and $\mathrm{C} 2$ ), the prior distributions of which are shown in the upper left panels. The numbers at nodes correspond to Bayesian posterior probabilities on the left and ML bootstrap probabilities on the right (values $<70 \%$ not shown). The numbers in brackets under the internodes indicate the

624 estimated mutation rates/Myr. Bars show credibility intervals as 95\% HPD 
626 Fig. 5 The Bayesian skyline plot for Gnathopogon caerulescens based on the HKY + I model. The 627 central bold line represents the median value for the relative effective female population size, and 628 the narrow line denotes the 95\% upper and lower credibility limits (95\% HPD) 

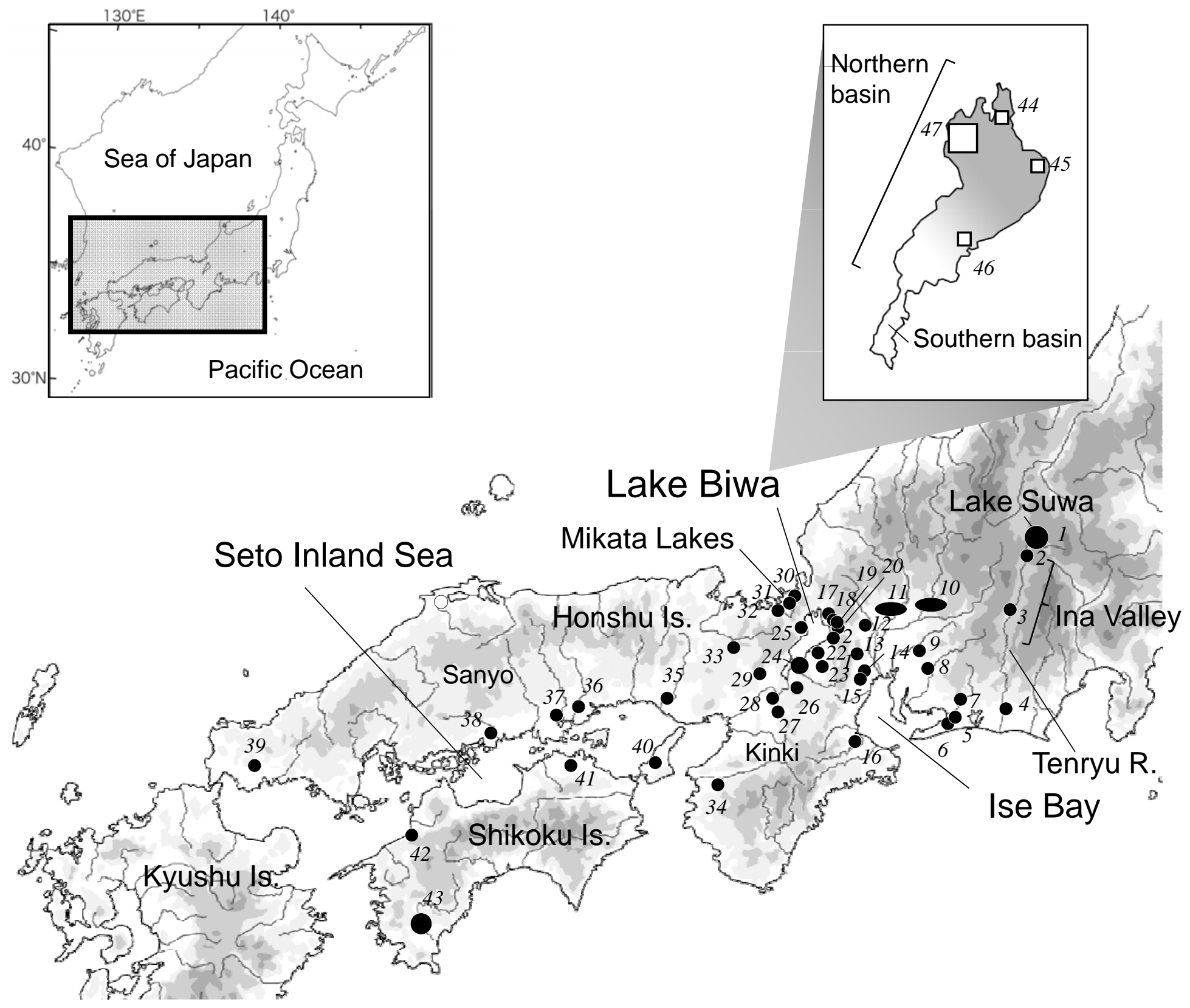

Fig. 1 
A Upper Tenryu R.

O Ise Bay-Lower Tenryu R.

- Around Lake Biwa and Kinki

$\star$ Mikata Lakes

$\triangle$ Sanyo and Shikoku

- Lake Biwa

(G. caerulescens)

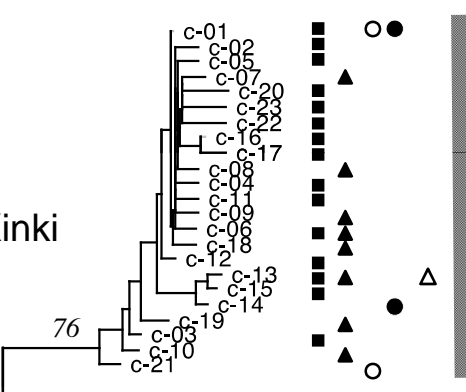

G. caerulescens: C

-
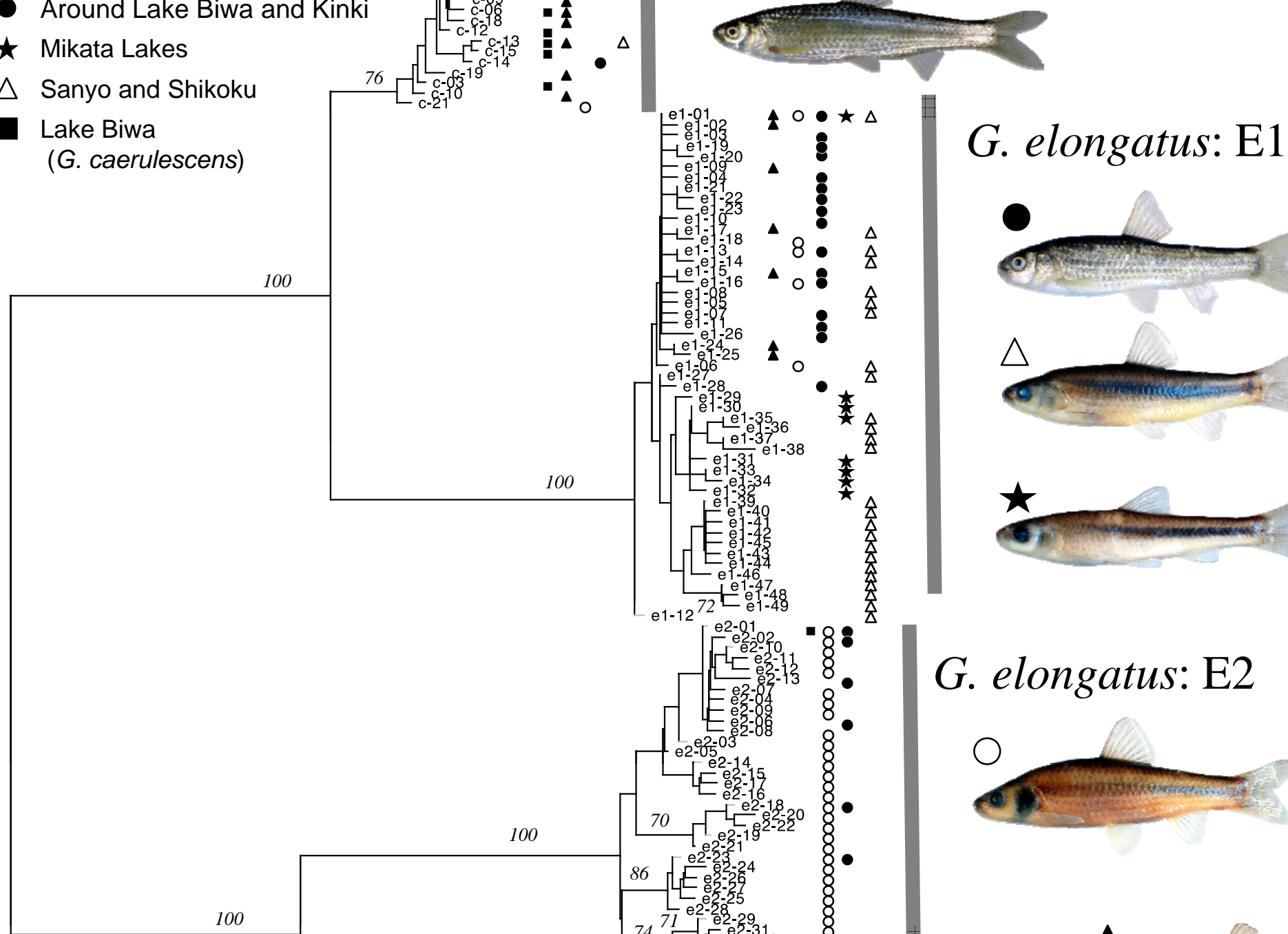

0.01 substitutions/site
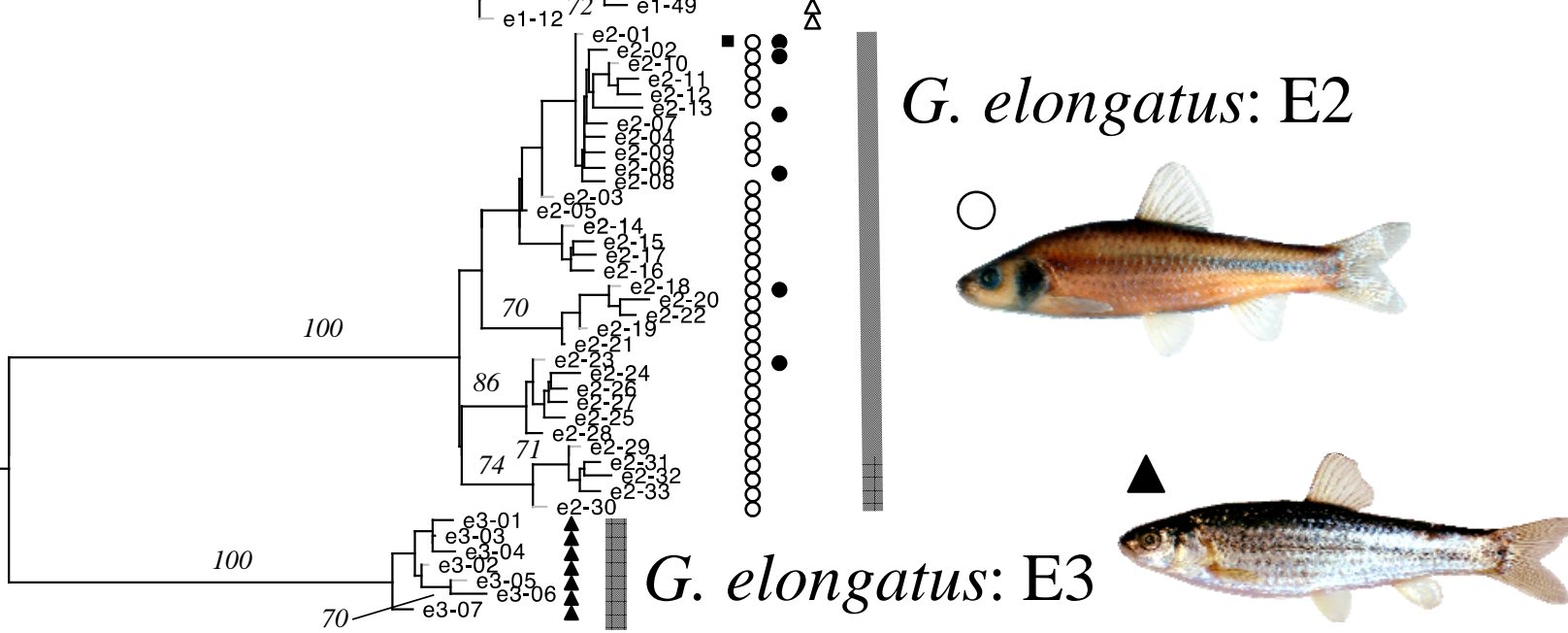

Fig. 2 

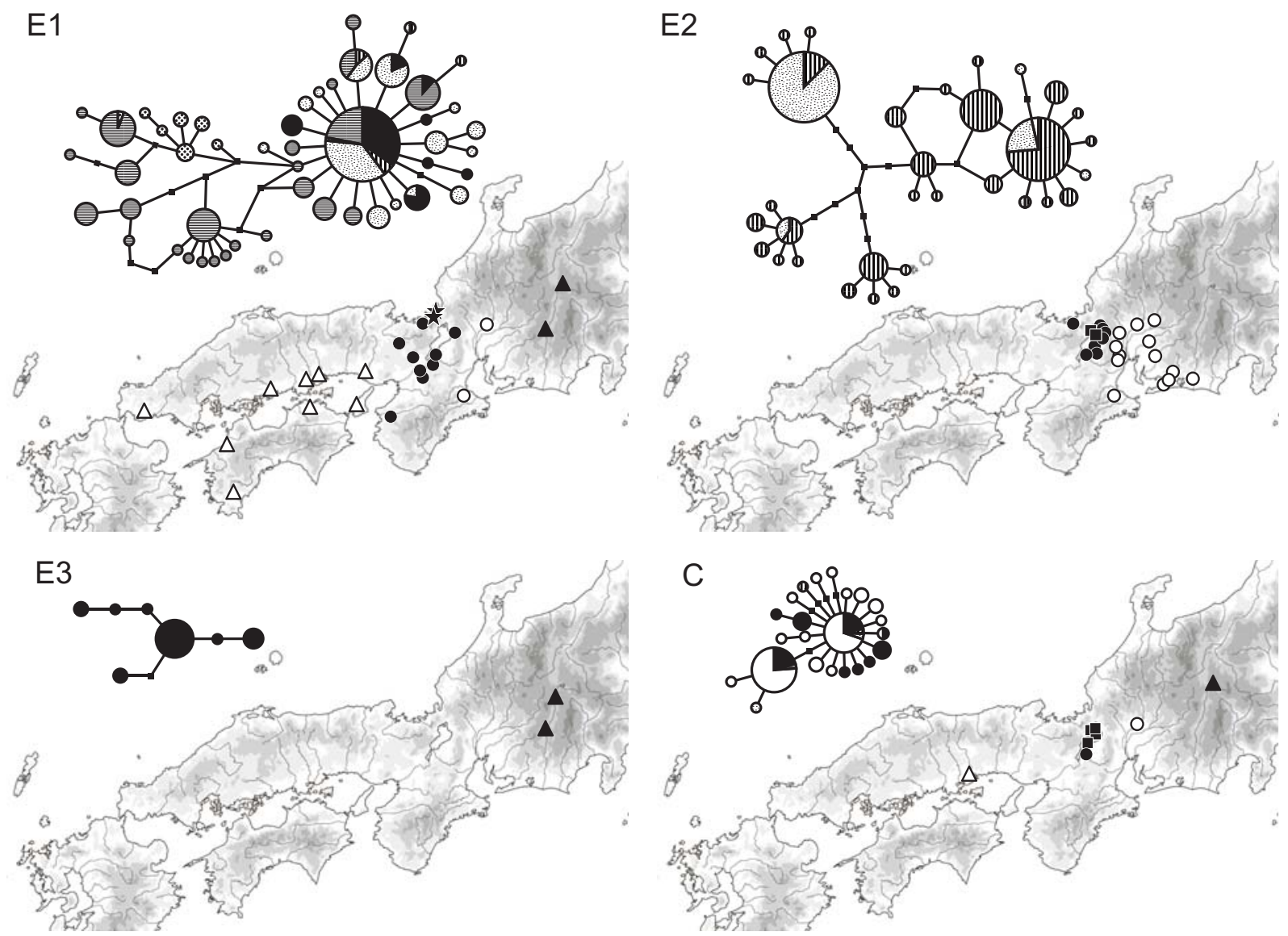

- Lake Biwa (G. caerulescens) Upper Tenryu R. $\mathbf{\Delta}$

$\triangle$ Sanyo and Shikoku

Fig. 3 


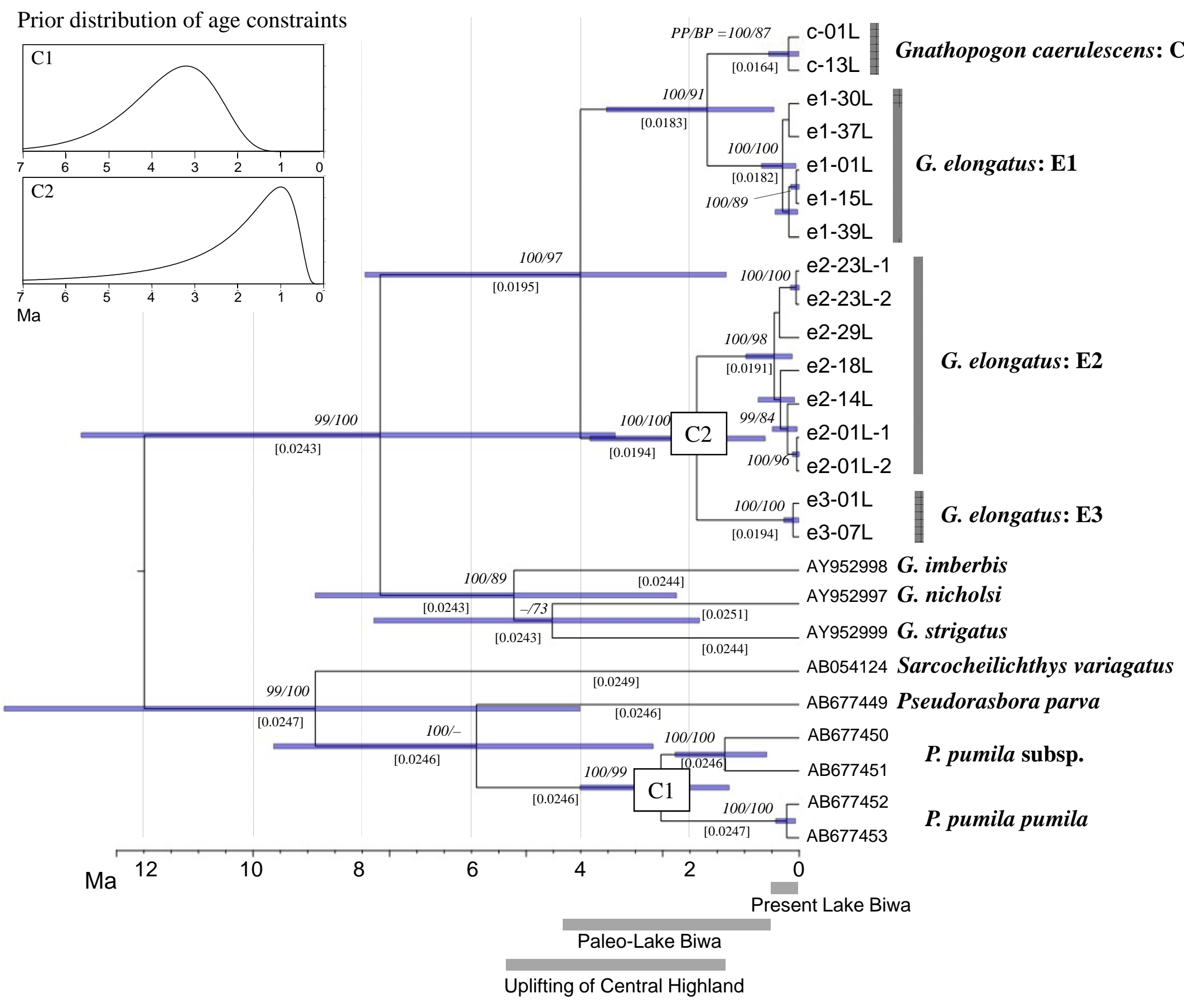

Fig. 4 


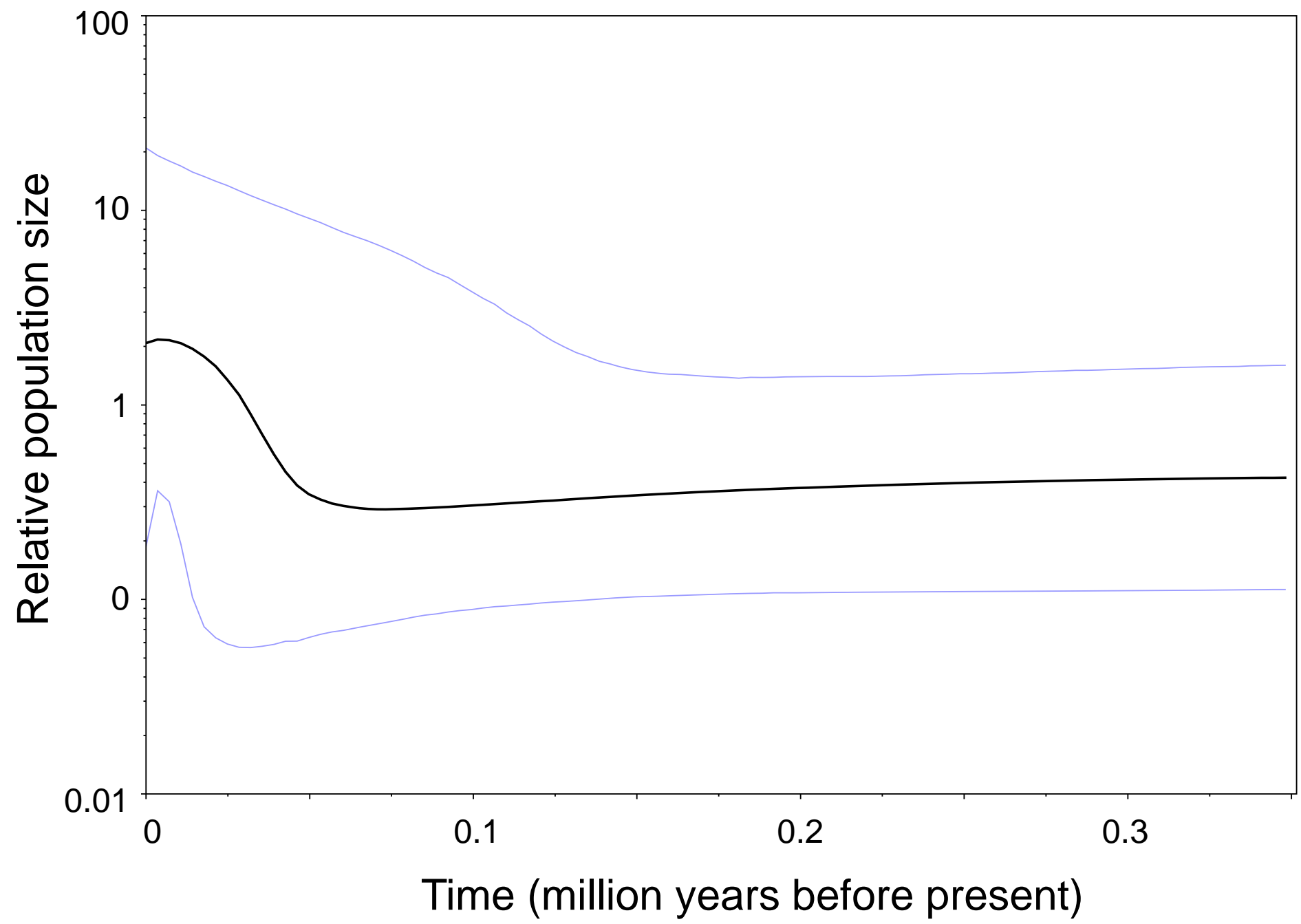

Fig. 5 
Table 1. Locality, number of specimens $(n)$, and genetic diversity indices of Gnathopogon populations examined

\begin{tabular}{|c|c|c|c|c|c|c|c|c|c|c|c|}
\hline \multirow{2}{*}{$\begin{array}{l}\text { Regional } \\
\text { group }\end{array}$} & \multirow{2}{*}{$\begin{array}{l}\text { Populat } \\
\text { ion } \\
\text { code }\end{array}$} & \multirow{2}{*}{$\begin{array}{l}\text { River; river/lake } \\
\text { system }\end{array}$} & \multirow[b]{2}{*}{ Locality } & \multirow[b]{2}{*}{$n$} & \multicolumn{4}{|c|}{ mtDNA groups } & \multirow[b]{2}{*}{$k$} & \multirow[b]{2}{*}{$h$} & \multirow[b]{2}{*}{$\pi$} \\
\hline & & & & & E1 & E2 & E3 & $\mathrm{C}$ & & & \\
\hline \multirow{2}{*}{\multicolumn{12}{|c|}{$\begin{array}{l}\text { Gnathopogon elongatus } \\
\text { Nagano }\end{array}$}} \\
\hline & & & & & & & & & & & \\
\hline & 1 & $\begin{array}{l}\text { Lake Suwa and its } \\
\text { inlets }\end{array}$ & $\begin{array}{l}\text { Suwa, Nagano } \\
\text { Prefecture }\end{array}$ & 63 & $41 *$ & - & - & $22 *$ & 17 & 0.811 & 0.021 \\
\hline & 2 & $\begin{array}{l}\text { Creek; upper Tenryu } \\
\text { River }\end{array}$ & $\begin{array}{l}\text { Kamiina, } \\
\text { Nagano Pref. }\end{array}$ & 16 & - & - & 16 & - & 3 & 0.433 & 0.002 \\
\hline & 3 & $\begin{array}{l}\text { Creek; upper Tenryu } \\
\text { River }\end{array}$ & $\begin{array}{l}\text { Iida, Nagano } \\
\text { Pref. }\end{array}$ & 15 & $5^{*}$ & - & 10 & - & 8 & 0.886 & 0.042 \\
\hline \multicolumn{12}{|l|}{ Shizuoka } \\
\hline & 4 & $\begin{array}{l}\text { Ichiunsai R.; lower } \\
\text { Tenryu R. }\end{array}$ & $\begin{array}{l}\text { Iwata, Shizuoka } \\
\text { Pref. }\end{array}$ & 13 & - & 13 & - & - & 5 & 0.628 & 0.001 \\
\hline \multicolumn{12}{|c|}{ 1спу уи. } \\
\hline & 5 & A creek; Umeda R. & $\begin{array}{l}\text { Toyohashi, } \\
\text { Aichi Pref. }\end{array}$ & 7 & - & 7 & - & - & 3 & 0.667 & 0.001 \\
\hline & 6 & Kamida R. & $\begin{array}{l}\text { Toyohashi, } \\
\text { Aichi Pref. }\end{array}$ & 4 & - & 4 & - & - & 2 & 0.667 & 0.006 \\
\hline & 7 & Toyo R. & $\begin{array}{l}\text { Shinshiro, Aichi } \\
\text { Pref. }\end{array}$ & 2 & - & 2 & - & - & 2 & 1.000 & 0.002 \\
\hline & 8 & $\begin{array}{l}\text { Yashita R., } \\
\text { Yahagi-furu R.; } \\
\text { Yahagi R. }\end{array}$ & $\begin{array}{l}\text { Toyota and } \\
\text { Nishio, Aichi } \\
\text { Pref. } \\
\text { Nagoya and }\end{array}$ & 22 & - & 22 & - & - & 5 & 0.338 & 0.001 \\
\hline & 9 & Ponds; Shonai River & $\begin{array}{l}\text { Nagakute, Aichi } \\
\text { Pref. }\end{array}$ & 19 & - & 19 & - & - & 6 & 0.708 & 0.010 \\
\hline & 10 & $\begin{array}{l}\text { Ponds and streams; } \\
\text { Kiso R. }\end{array}$ & $\begin{array}{l}\text { Sofue and } \\
\text { Ichinomiya, } \\
\text { Aichi Pref.; } \\
\text { Hashima, } \\
\text { Minokamo and } \\
\text { Yaotsu, Gifu } \\
\text { Pref. }\end{array}$ & 23 & - & 23 & - & - & 7 & 0.712 & 0.008 \\
\hline & 11 & $\begin{array}{l}\text { Ponds and streams; } \\
\text { Nagara R. }\end{array}$ & $\begin{array}{l}\text { Ijira and Kaizu, } \\
\text { Gifu Pref. }\end{array}$ & 8 & 5 & 1 & - & $2 *$ & 5 & 0.786 & 0.037 \\
\hline & 12 & Creeks; Ibi R. & $\begin{array}{l}\text { Yoro and Ogaki, } \\
\text { Gifu Pref. }\end{array}$ & 17 & - & 17 & - & - & 5 & 0.757 & 0.008 \\
\hline & 13 & A pond; Inabe R. & Inabe, Mie Pref. & 3 & - & 3 & - & - & 2 & 0.667 & 0.001 \\
\hline & 14 & Kaizo R. & $\begin{array}{l}\text { Yokkaichi, Mie } \\
\text { Pref. }\end{array}$ & 3 & - & 3 & - & - & 2 & 0.667 & 0.011 \\
\hline & 15 & $\begin{array}{l}\text { Kabake R.; Tenpaku } \\
\text { R. }\end{array}$ & $\begin{array}{l}\text { Yokkaichi, Mie } \\
\text { Pref. }\end{array}$ & 4 & - & 4 & - & - & 2 & 0.500 & 0.008 \\
\hline & 16 & $\begin{array}{l}\text { Kushida R. and } \\
\text { Harai R.; Kushida } \\
\text { R. }\end{array}$ & $\begin{array}{l}\text { Matsusaka, Mie } \\
\text { Pref. }\end{array}$ & 14 & 4 & 10 & - & - & 6 & 0.681 & 0.043 \\
\hline \multicolumn{12}{|l|}{$\begin{array}{l}\text { Around Lake } \\
\text { Biwa }\end{array}$} \\
\hline & 17 & Yogo R. & $\begin{array}{l}\text { Takatsuki, Shiga } \\
\text { Pref. }\end{array}$ & 2 & - & 2 & - & - & 2 & 1.000 & 0.002 \\
\hline & 18 & Kawamichi R. & $\begin{array}{l}\text { Nagahama, } \\
\text { Shiga Pref. }\end{array}$ & 5 & - & 5 & - & - & 3 & 0.700 & 0.010 \\
\hline & 19 & A pond & $\begin{array}{l}\text { Nagahama, } \\
\text { Shiga Pref. }\end{array}$ & 8 & 8 & - & - & - & 4 & 0.821 & 0.002 \\
\hline & 20 & $\begin{array}{l}\text { Nagahama-shinsen } \\
\text { R. }\end{array}$ & $\begin{array}{l}\text { Nagahama, } \\
\text { Shiga Pref. }\end{array}$ & 8 & - & 8 & - & - & 2 & 0.536 & 0.007 \\
\hline & 21 & Anjiki R. & $\begin{array}{l}\text { Hikone, Shiga } \\
\text { Pref. }\end{array}$ & 14 & - & 14 & - & - & 1 & 0.000 & 0.000 \\
\hline & 22 & Daidoh R. & $\begin{array}{l}\text { Notogawa, } \\
\text { Shiga Pref. }\end{array}$ & 12 & - & 12 & - & - & 1 & 0.000 & 0.000 \\
\hline & 23 & Hino R. & $\begin{array}{l}\text { Hino, Shiga } \\
\text { Pref. }\end{array}$ & 16 & - & 16 & - & - & 2 & 0.325 & 0.004 \\
\hline & 24 & Creeks & $\begin{array}{l}\text { Ritto, } \\
\text { Moriyama, and } \\
\text { Kusatsu, Shiga } \\
\text { Pref. }\end{array}$ & 22 & 16 & 4 & - & 2 & 6 & 0.788 & 0.036 \\
\hline & 25 & Creeks & Adogawa, Shiga & 13 & - & 13 & - & - & 4 & 0.423 & 0.006 \\
\hline
\end{tabular}


Yodo River

system

$\begin{array}{ll}26 & \text { Daido R. } \\ 27 & \text { Fugenji R. } \\ 28 & \text { Nunome R.; Kizu R. } \\ 29 & \text { Creek; Hozu R. }\end{array}$

Northern

Kinki

$\begin{array}{ll}30 & \text { Mikata Lakes } \\ 31 & \text { Hasu R.; Mikata L. } \\ 32 & \text { Kita R. } \\ 33 & \text { Takaya R.; Yura R. }\end{array}$

Southern

Kinki

Sanyo

Southern

Shikoku

Ushiro R.,

Uchigawa R., Mima R., and a pond; Shimanto R.

Gnathopogon caerulescens

Lake Biwa

(LBW)

$\begin{array}{cc}44 & \text { Lake Biwa } \\ 45 & \text { Lake Biwa } \\ 46 & \text { Lake Biwa } \\ 47 & \text { Lake Biwa }\end{array}$

Creeks; Kinokawa

Shitoori R.; Mihara R.
Pref.

$\begin{array}{lcccccccc}\begin{array}{l}\text { Otsu, Shiga } \\ \text { Pref. }\end{array} & 8 & 8 & - & - & - & 3 & 0.679 & 0.002 \\ \begin{array}{l}\text { Kyotanabe, } \\ \text { Kyoto Pref. }\end{array} & 10 & 10 & - & - & - & 2 & 0.200 & 0.000 \\ \begin{array}{l}\text { Kasagi, Kyoto } \\ \text { Pref. }\end{array} & 6 & 6 & - & - & - & 2 & 0.600 & 0.001 \\ \begin{array}{l}\text { Kameoka, } \\ \text { Kyoto Pref. }\end{array} & 15 & 15 & - & - & - & 7 & 0.838 & 0.003 \\ \end{array}$

Mikata, Fukui

Pref.

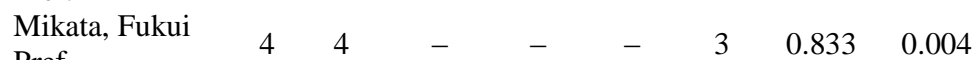

Pref.

$\begin{array}{llllllllll}\text { Obama, Fukui } & 8 & 0 & 8 & - & - & 2 & 0.536 & 0.007\end{array}$

Pref.

Mizuho, Kyoto

Pref.

Katsuragi,

Wakayama Pref.

1212

$0.455 \quad 0.001$

Kakogawa,

Hyogo Pref.

1212

Seto, Okayama

Pref.

Okayama,

Okayama Pref.

Fukuyama,

Hiroshima Pref.

Ube, Yamaguchi

Pref.

Minami-awaji,

Hyogo Pref.

(15)

$32-\begin{array}{llllll} & - & 1^{*} & 2 & 0.667 & 0.031\end{array}$

$\begin{array}{llllllll}15 & 15 & - & - & - & 9 & 0.905 & 0.006\end{array}$

$\begin{array}{llllllll}10 & 10 & - & - & - & 5 & 0.756 & 0.004\end{array}$

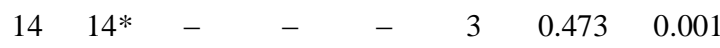

$\begin{array}{lllllllll}16 & 16 & - & - & - & 4 & 0.758 & 0.006\end{array}$

$\begin{array}{lllllllllll}\text { Takamatsu, } & 16 & 16 & - & - & - & 4 & 0.525 & 0.005\end{array}$

$\begin{array}{lllllllll}\text { Iyo, Ehime Pref. } & 5 & 5 & - & - & - & 3 & 0.700 & 0.006\end{array}$

Shimanto,

$\begin{array}{llllllllll}\text { Kochi Pref., and } & 15 & 15^{*} & - & - & - & 1 & 0.000 & 0.000\end{array}$

Uwajima,

Ehime Pref.

\begin{tabular}{|c|c|c|c|c|c|c|c|c|}
\hline $\begin{array}{l}\text { Kohoku, Shiga } \\
\text { Pref. }\end{array}$ & 8 & - & - & - & 8 & 3 & 0.607 & 0.003 \\
\hline $\begin{array}{l}\text { Hikone, Shiga } \\
\text { Pref. }\end{array}$ & 3 & - & 1 & - & 2 & 3 & 1.000 & 0.051 \\
\hline $\begin{array}{l}\text { Omihachiman, } \\
\text { Shiga Pref. }\end{array}$ & 14 & - & - & - & 14 & 7 & 0.857 & 0.003 \\
\hline $\begin{array}{l}\text { Oura and Imazu, } \\
\text { Shiga Pref. }\end{array}$ & 31 & - & 1 & - & 30 & 10 & 0.753 & 0.008 \\
\hline
\end{tabular}

*Haplotypes highly probably originated from artificially introduced fish (see text)

$k$ Number of haplotypes, $h$ haplotype diversity, $\pi$ nucleotide diversity 
Table 2. Genetic distances and estimated divergence time between major lineages of Japanese Gnathopogon species based on 1,125-bp mtDNA cytochrome $b$ sequences

\begin{tabular}{lllll}
\hline & $\mathrm{C}+\mathrm{E} 1$ vs. E2 $+\mathrm{E} 3$ & $\mathrm{C}$ vs. E1 & E2 vs. E3 ${ }^{\mathrm{a}}$ & $\begin{array}{l}\text { Pseudorasbora pumila } \\
\text { subspp. }^{\mathrm{b}}\end{array}$ \\
\hline$p$ distance & $0.0771 \pm 0.0042$ & $0.0335 \pm 0.0020$ & $0.0471 \pm 0.0010$ & $0.0742 \pm 0.0017$ \\
GTR + G + I distance & $0.1089 \pm 0.0086$ & $0.0369 \pm 0.0021$ & $0.0551 \pm 0.0014$ & $0.0988 \pm 0.0033$ \\
tMRCA (Myr) & $4.01 \pm 0.10$ & $1.68 \pm 0.04$ & $1.88 \pm 0.05$ & $2.53 \pm 0.01$ \\
Mean clock rate (/Myr) & {$[1.34,7.95]$} & {$[0.47,3.53]$} & {$[0.62,3.83]$} & {$[1.28,4.01]$} \\
$p$ distance/Myr/lineage & 0.0195 & 0.0183 & 0.0194 & 0.0246 \\
\hline
\end{tabular}

Data are shown as mean \pm standard deviation

In brackets, $95 \%$ confidence interval (highest posterior density) is shown

${ }^{\text {a }}$ The node was used as calibration point (C2 in Fig. 3)

${ }^{\mathrm{b}}$ The node was used as calibration point ( $\mathrm{C} 1$ in Fig. 3) 
Appendix Table S1. Haplotypes and their frequencies of Gnathopogon populations examined

\begin{tabular}{|c|c|c|}
\hline Population code & Haplotype (frequency) & GEDIMAP $^{\mathrm{a}}$ population ID \\
\hline$T_{1}$ & $\begin{array}{l}\text { c-1 (5), c-6 (1), c-7 (3), c-8 (1), c-9 (1), c-10 (1), c-13 (6), c-18 } \\
\text { (3), c-19 (1), e1-1 (26), e1-2 (4), e1-9 (4), e1-15 (2), e1-17 (2), } \\
\text { e1-19 (1), e1-24 (1), e1-25 (1) }\end{array}$ & P1382 \\
\hline 2 & e3-1 (12), e3-6 (2), e3-7 (2) & P1383 \\
\hline 3 & $\begin{array}{l}\text { e1-1 (1), e1-2 (3), e1-15 (1), e3-1 (3), e3-2 (1), e3-3 (1), e3-4 } \\
(4), \text { e3-5 (1) }\end{array}$ & P1384 \\
\hline 4 & e2-29 (8), e2-30 (1), e2-31 (1), e2-32 (1), e2-33 (2) & $\mathrm{P} 1385$ \\
\hline 5 & e2-14 (2), e2-15 (1), e2-16 (4) & P1386 \\
\hline 6 & e2-14 (2), e2-18 (2) & P1387 \\
\hline 7 & e2-14 (1), e2-17 (1) & P1388 \\
\hline 8 & e2-8 (1), e2-10 (18), e2-11 (1), e2-12 (1), e2-14 (1) & P1389 \\
\hline 9 & e2-1 (10), e2-18 (2), e2-22 (1), e2-23 (2), e2-26 (3), e2-28 (1) & P1390 \\
\hline 10 & e2-1 (12), e2-4 (3), e2-7 (1), e2-18 (3), e2-20 (1), e2-23 (2), & P1391 \\
\hline 11 & c-1 (1), c-21 (1), e1-1 (4), e1-6 (1), e2-19 (1) & P1392 \\
\hline 12 & e2-1 (7), e2-9 (5), e2-18 (2), e2-21 (1), e2-23 (2) & P1393 \\
\hline 13 & e2-1 (1), e2-5 (2) & P1394 \\
\hline 14 & e2-1 (1), e2-24 (2) & P1395 \\
\hline 15 & e2-1 (3), e2-25 (1) & P1396 \\
\hline 16 & e2-1 (8), e2-2 (1), e2-3 (1), e1-13 (2), e1-16 (1), e1-18 (1) & P1397 \\
\hline 17 & e2-1 (1), e2-6 (1) & P1398 \\
\hline 18 & e2-1 (3), e2-18 (1), e2-23 (1) & P1399 \\
\hline 19 & e1-1 (1), e1-4 (2), e1-7 (3), e1-15 (2) & P1400 \\
\hline 20 & e2-1 (5), e2-18 (3) & P1401 \\
\hline 21 & e2-18 (14) & P1402 \\
\hline 22 & e2-18 (12) & P1403 \\
\hline 23 & e2-18 (13), e2-23 (3) & P1404 \\
\hline 24 & c-1 (1), c-14 (1), e1-1 (7), e1-2 (2), e1-13 (7), e2-18 (4) & $\mathrm{P} 1405$ \\
\hline 25 & e2-1 (1), e2-2 (1), e2-13 (1), e2-18 (10) & P1406 \\
\hline 26 & e1-1 (4), e1-15 (1), e1-22 (3) & P1407 \\
\hline 27 & e1-1 (1), e1-15 (9) & P1408 \\
\hline 28 & e1-1 (3), e1-4 (3) & P1409 \\
\hline 29 & e1-1 (4), e1-10 (2), e1-11 (1), e1-16 (1), e1-20 (1), e1-21 (5), & P1410 \\
\hline 30 & e1-1 (1), e1-30 (3), e1-33 (1), e1-31 (2), e1-35 (1) & P1411 \\
\hline 31 & e1-29 (1), e1-32 (2), e1-34 (1) & $\mathrm{P} 1412$ \\
\hline 32 & e2-1 (3), e2-18 (5) & P1413 \\
\hline 33 & $\mathrm{e} 1-26(3)$ & P1414 \\
\hline 34 & e1-1 (9), e1-3 (1), e1-15 (1), e1-28 (1) & P1415 \\
\hline 35 & $\begin{array}{l}\text { e1-1 (1), e1-8 (1), e1-35 (3), e1-36 (1), e1-39 (2), e1-40 (1), } \\
\text { e1-47 (2), e1-48 (1) }\end{array}$ & P1416 \\
\hline 36 & $\mathrm{c}-13(1), \mathrm{e} 1-37(2)$ & P1417 \\
\hline 37 & $\begin{array}{l}\text { e1-1 (3), e1-6 (1), e1-27 (1), e1-37 (2), e1-38 (1), e1-39 (4), } \\
\text { e1-41 (1), e1-42 (1), e1-43 (1) }\end{array}$ & P1418 \\
\hline 38 & e1-37 (2), e1-39 (5), e1-44 (1), e1-45 (1), e1-46 (1) & P1419 \\
\hline 39 & e1-1 (10), e1-5 (3), e1-7 (1) & P1420 \\
\hline 40 & e1-6 (3), e1-13 (6), e1-14 (2), e1-49 (5) & $\mathrm{P} 1421$ \\
\hline 41 & e1-1 (2), e1-8 (1), e1-35 (11), e1-47 (2) & $\mathrm{P} 1422$ \\
\hline 42 & e1-1 (1), e1-12 (1), e1-35 (3) & P1423 \\
\hline 43 & e1-17 (15) & $\mathrm{P} 1424$ \\
\hline 44 & c-1 (2), c-13 (5), c-23 (1) & $\mathrm{P} 1425$ \\
\hline 45 & $\mathrm{c}-1(1), \mathrm{c}-2(1), \mathrm{e} 2-1(1)$ & P1426 \\
\hline 46 & c-1 (4), c-3 (1), c-6 (1), c-12 (2), c-13 (4), c-15 (1), c-16 (1) & P1427 \\
\hline 47 & $\begin{array}{l}\mathrm{c}-1(9), \mathrm{c}-3(1), \mathrm{c}-4(2), \mathrm{c}-5(1), \mathrm{c}-11(1), \mathrm{c}-13(13), \mathrm{c}-17(1), \mathrm{c}- \\
20(1), \mathrm{c}-22(1), \mathrm{e} 2-1(1)\end{array}$ & P1428 \\
\hline
\end{tabular}

${ }^{a}$ http://gedimap.zool.kyoto-u.ac.jp

Population codes correspond to those shown in Table 1 and Fig. 1

Haplotypes begin with c are those of G. caerulescens; haplotypes begin with e1-e3 are those of the E1-E3 clades of G. elongatus

Frequencies for each haplotype are shown in parentheses

Sequences of the haplotypes were deposited in DDBJ/EMBL/GenBank (accession numbers AB677321-AB677440) 